\title{
THE IMPACT OF DEMOGRAPHIC TRANSITION ON TAX REVENUE IN INDONESIA
}

\author{
Yuventus Effendi ${ }^{a}$, Wahyu Hidayat ${ }^{b}$, Asep Nurwanda ${ }^{c}$ \\ a Fiscal Policy Agency, Jakarta. Email: yuventus.e@gmail.com \\ b Fiscal Policy Agency, Jakarta. Email: why212@gmail.com \\ c Fiscal Policy Agency, Jakarta. Email: asepnurwanda@gmail.com
}

\begin{abstract}
In the next few decades, Indonesia will experience significant demographic transition such as increasing productive age cohort and ageing populations. This study aims to construct a framework to analyze the nexus between demographic transition, Indonesian economy, and the state budget. This study uses 3Ps (productivity, proportion, and participation) model as a basic framework. Further, this paper differentiates between demographic related tax revenue and non-demographic. We find that productivity is the main engine of the economic growth in both historical data points and in our future projection. Also, ageing populations would hamper the economy in the future through lower productivity. Hence in the short run, taxation agenda should focus on extending tax base to capture the demographic transition. In the long run, maintaining taxpayers to keep paying tax properly is an appropriate strategy. These could be done by early tax education and transparency in managing tax revenue.
\end{abstract}

Keywords: demographic transition, state budget, tax revenue

\section{ABSTRAK}

Dalam beberapa dekade ke depan, Indonesia akan mengalami transisi demografi yang signifikan seperti bertambahnya kelompok penduduk usia produktif dan populasi yang menua. Oleh karena itu, studi ini bertujuan untuk membangun kerangka dasar untuk menganalisa hubungan antara transisi demografi dan ekonomi Indonesia, termasuk Anggaran Pendapatan dan Belanja Negara (APBN). Studi ini menggunakan model 3P (produktivitas, proporsi, dan partisipasi) sebagai kerangka dasar. Lebih lanjut, kajian ini memisahkan antara penerimaan pajak terkait demografi dan non-demografi. Kami menemukan bahwa produktivitas merupakan mesin penggerak utama untuk pertumbuhan ekonomi baik pada data historical maupun proyeksi ke depan. Lebih lanjut, populasi yang menua dapat mempengaruhi ekonomi melalui tingkat produktivitas yang lebih rendah di masa depan. Oleh karena itu, agenda perpajakan harus fokus dalam memperluas basis pajak untuk menangkap transisi demografi dalam jangka pendek. 
Dalam jangka panjang, memperta hankan pembayar pajak untuk membayar pajak dengan benar merupakan strategi yang sesuai. Semua ini dapat dicapai dengan pendidikan dini perpajakan dan transparansi pengelolaan penerimaan pajak.

\section{INTRODUCTION}

In recent years, Indonesia dependency ratio shows a declining trend up to 2030 before gradually increase as depicted in Figure 1. Declining dependency ratio implies that the number of the working-age group increases significantly, from approximately 160 million people in 2010 up to 210 million people in 2035, or equal to 50 million productive people increasing in 25 years ahead. Nevertheless, Figure 1 also reveals that after 2030, the group of people in 15-65 years old cohort will have slow down growth rate while the group of people categorised in 65 years old cohort will increase significantly.
In terms of State Budget, from revenue side, several issues are interlinked with this demographic transition. Firstly, despite increasing working-age populations in the recent years, the ratio of registered taxpayers to total labor force has not been increased significantly. In 2008 the number of registered Personal Taxpayer was about 8.38 million taxpayers which was only approximately $7.79 \%$ of total labor force. In 2015, the percentage increased thrice up to 22.53\% (DJP Annual Report, various year). However, this percentage still low compare to other countries. Araki and Claus (2014) reveals that in 2011 the ratio for Indonesia was around $17.2 \%$ which relatively low compared to Malaysia and Thailand (56.8\% and $23.7 \%$ respectively). Secondly, in the long run, after 2030, non-productive populations will increase gradually, which implies that probably less tax revenues can be collected. Thus, Indonesia tax authority has a significant issue in extending the tax base to represent increasing number of productive populations in the short run. While in the next few decades, the issue of shrinking tax base will appear.

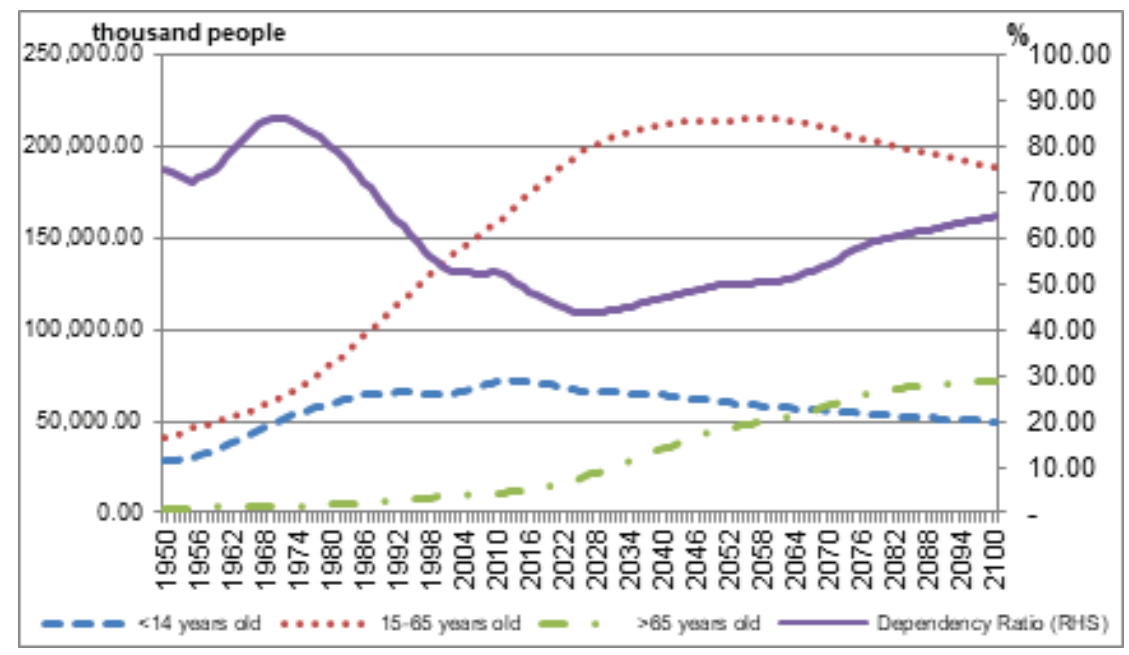

Figure 1 Indonesian Dependency Ratio and Age Cohorts Source: Statistics Indonesia (BPS), Authors' calculation 
Dalam jangka panjang, memperta hankan pembayar pajak untuk membayar pajak dengan benar merupakan strategi yang sesuai. Semua ini dapat dicapai dengan pendidikan dini perpajakan dan transparansi pengelolaan penerimaan pajak.

\section{INTRODUCTION}

Therefore, this study aims to estimate and predict the impacts of Indonesian demographic transition to the state budget, in particular at the revenue side. This study argues that this demographic changes in the long run will have significant impacts on tax revenue through changes in income per capita as well as Gross Domestic Product (GDP). At the best knowledge of the authors, this study is the first attempt in Indonesian case to construct a relationship between demographic transition and the state budget, including detail estimation on the revenue side such as demographic related income tax. The rest of this paper is organized as follow: next section summarizes recent literatures on demographic, economic growth, and the state budget. The following section elaborates methodology and data in details. Research results and discussion will be presented after. The last part of this paper concludes the research.

\section{LITERATURE REVIEW}

Several previous studies show the correlation between demographic changes and a wide range of economic aspects including economic growth (Chong-Bum \& Seung-Hoon, 2006), GDP per capita (Lee \& Mason, 2007; Choudhry \& Elhorst, 2010; de la Croix et al., 2009), and government spending (Shoven, Topper \& Wise, 1994; Wolf \& Amirkhanyan, 2010).

Chong-Bum and Seung-Hoon (2006) argue that the relationship between demographic transition and economic growth is an inverted- $U$ shape; increasing when dependency ratio is very low and then decreasing due to the ageing populations.

In relation to GDP per capita, Lee and Mason (2007) find evidence that demographic transition occurred in Taiwan gave favourable effect to the economy in term of the higher growth rate of income per capita. This higher growth rate is a result of changes in age structure due to a different pace of total populations and working age populations growth. Similarly to Lee and Mason (2007), Choudhry and Elhorst (2010) also find that in China, India, and Pakistan, a decline in the child dependency ratio has a positive impact on the growth of GDP per capita. In a longer period, de la Croix et al. (2009) find that demographic change is a key ingredient for determining the long-term growth of income per capita.

In studying the correlation between demographic transition and economic growth, there are several channels proposed in previous studies. Prskawetz et al. (2007) argue that demographic dividend is affected through two stages. 
First, it leads to a higher growth of output per capita through accounting and behavioural effects. The accounting effect assumes that there is an increasing ratio of producers to consumers in the economy while the behavioural effect assumes that there is a significant increasing in savings. Moreover, in term of behavioural effects, the role of demographic changes is significant in determining the productivity level through savings, investment, human capital development, and technological changes. Finally, the second phase occurs through increasing wealth to output ratio as a result of increasing in savings due to increasing longevity.

Perkins et al. (2013) and Oosthuizen (2014) argue that there is two channel by which the effect is channelled; first increase in working age group which result in the increase in income per capita, second the increase in saving rate and asset accumulation as income increase.

Related to government budget, Shoven, Topper and Wise (1994) find that populations transition affects government budget in several items related to demographic change, such as health expenditure. The health expenditure item tends to escalate due to elderly consumes more health services than younger age.

\section{METHODOLOGY AND DATA}

The literatures indicate that there is a nexus between demographic transition and economy. However, less study on how this demographic dynamic will affect revenue side of a country.
Improving income per capita as well as aggregate economy should support higher tax revenue. Similarly, increasing savings and investment should boost tax collections. This study provides a simple framework of correlation between demographic transition and economy, as well as state budget from revenue and expenditure sides as presented in Figure 2.

Figure 2 describes the framework of this study with Equation 1 as the main equation. Basically, Equation 1 decomposes income per capita into three distinct components such as productivity, participation rate, and proportion rate similar to Bloom et al. (2010) and Golley and Wei (2015).

$$
\frac{Y}{N}=\frac{Y}{E} \cdot \frac{E}{W A} \cdot \frac{W A}{N}
$$

where $\mathrm{Y}$ is the Gross Domestic Product (GDP), $\mathrm{N}$ is the total populations, $\mathrm{E}$ is the total labor force, and WA is the working age populations. The left-hand side term is GDP per capita while on the right-hand side is productivity, which is followed by participation rate and proportion of labor force to the total populations. These three components in the right-hand side is called 3P onward. 


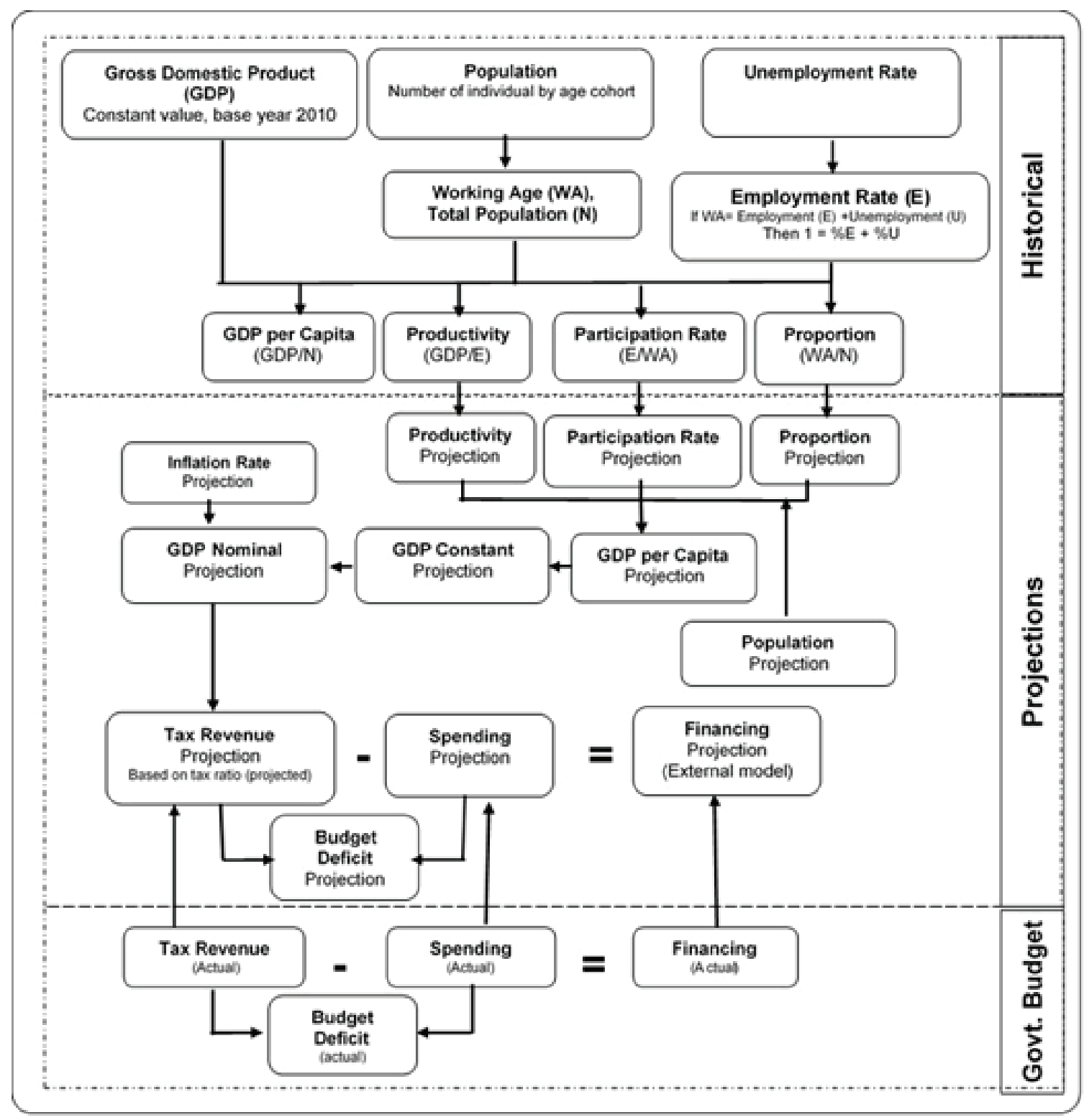

Figure 2 The Basic Framework Source: Authors' estimation.

There are several stages to decompose GDP per capita in Equation 1. The first step is to generate populations projection $^{2}$. Data of populations projection from Statistics Indonesia (BPS) which span up from 1950 to 2100 is sufficient at this stage 3 . Secondly, after the projected demographic population is available, this study needs to project the participation rate into labor force for each specific age cohort. The projection is simply utilised the historical trend as a ratio of the labor force and working age populations (Australian Treasury, 2015). Finally, economic projections which cover economic projection framework, 
such as inflation rate to generate nominal value for GDP from real GDP. While historical 3Ps can be constructed using available data, this study needs to use several assumptions to project 3Ps in the long run in the second stage. To simplify the calculation, this study assumes that productivity is constant, based on average value of productivity in the period of 2000 to 2015. Also, the participation rate is constructed by projecting the participation rates for each age cohort by utilising Vector Autoregressive (VAR) approach ${ }^{4}$. The participation rate is then multiplied to the number of each age groups to obtain the labor force per cohort. Then, the proportion of working age is simply a ratio of working age group compared to total populations which obtained from Statistics Indonesia.

Similar to Bloom et al. (2010) and Golley and Wei (2015), the growth rate for each 3P component is calculated in this paper and is followed by the growth rate of GDP per capita computation. Also, GDP per capita at the constant price can be calculated by utilising the 2015 GDP per capita. To transform the constant GDP per capita into GDP at the constant value, this study simply multiplies GDP per capita value with the total populations.
Once the constant value is obtained, nominal GDP can be computed by assuming a certain level of the inflation rate in the future as mentioned earlier.

Finally, the last important stage is to compute and estimate the state budget. This study differentiates into two parts. First, calculation of revenue based on demographic and non-demographic variables. Second, computation of expenditure based on the GDP growth. Regarding of the revenue side, this study calculates by selecting particular several articles which correlate to demographic such as Article 21 and Article 25/29 of Income Tax Law which are relate to Personal Taxpay$\mathrm{ers}^{5}$. Article 21 is a tax revenue received from the employee. This type of tax revenue is a directly correlates to the number of the employee who has Tax Identification Number (TIN). Article 25/29 Personal Taxpayers to some extends captures entrepreneurship tax revenue. Further disaggregation between pure entrepreneur and employee cannot be done since limitation on data availability.

To projecting the tax revenue from Article 21 and Article 25/29 in the long run, this study simply taking natural logarithm for the number of the labor force and tax revenues for each article. Afterwards, this study estimates the parameters by utilising a linear regression?

\footnotetext{
2Following Australian Treasury (2015), this study needs to disaggregate population into age-specific cohorts.

3 In developing intergenerational report in Australia, Australian Treasury develops their own population projection even though other unit may have construct similar projection.

4VAR approach is utilised in order to accommodate assumption that in the certain period, the under-age labor (15-19 years old cohort) is diminishing over time.

5The Article 25 is a routine monthly payment of personal taxpayer, while Article 29 is payable tax after the tax payer do a self-assessment on the whole one year.

6The main drawback of this estimation is it is a partial estimation, assumes that other factors held constant (ceteris paribus). Other methods such as general equilibrium could be done if there is more comprehensive data available, such as contribution of each taxpayers based on age, occupation, income level, and location based. Unfortunately, those data are not available publicly.
} 
For the non-demographic tax revenue such as Article 22, 23, 24, and 4(2), it is assumed that the tax revenues are based on particular proportion to nominal GDP (see Table 1 Appendices). To obtain the percentage, each component of revenue, both tax and non-tax as well as grants is divided to nominal GDP. Then, taking an average value for each component. This average proportion is multiplied to the nominal GDP. After each demographic and non-demographic are computed, summation of all component will construct revenue projections.

Regarding of expenditure side, it is assumed that expenditure grows according to GDP growth. In order to calculate mandatory spending, it is assumed also that there is particular proportion allocated to education, health, and local government transfer. In this study, it is assumed that there are $20 \%$ allocated to education spending each year, as well as 5\% for health spending. Moreover, this study also assumes that $50 \%$ of the state budget goes to the local government in form of General Allocation Fund, Specific Allocation Fund, and Village Fund. The next step is to calculate budget deficit, which is simply a gap between revenue and expenditure. To generate a ratio of deficit to GDP, it is assumed a particular inflation rate which is constant over time. This inflation rate inflates the constant GDP from the previous part. Definitions

\section{RESULTS AND DISCUSSION 4.1 Participation Rate}

In order to decompose income per capita into three distinct components in Equation 1 , this study assumes the projected productivity rate from 2016 to 2050 at a constant rate $3.6 \%$. The number is basically derived by averaging the productivity growth rate from period 2000 to $2015^{7}$. Other component, Proportion Rate is estimated by using dataset projection of the populations from Statistics Indonesia which is relatively straightforward. While the last component, participation rate is estimated as follow.

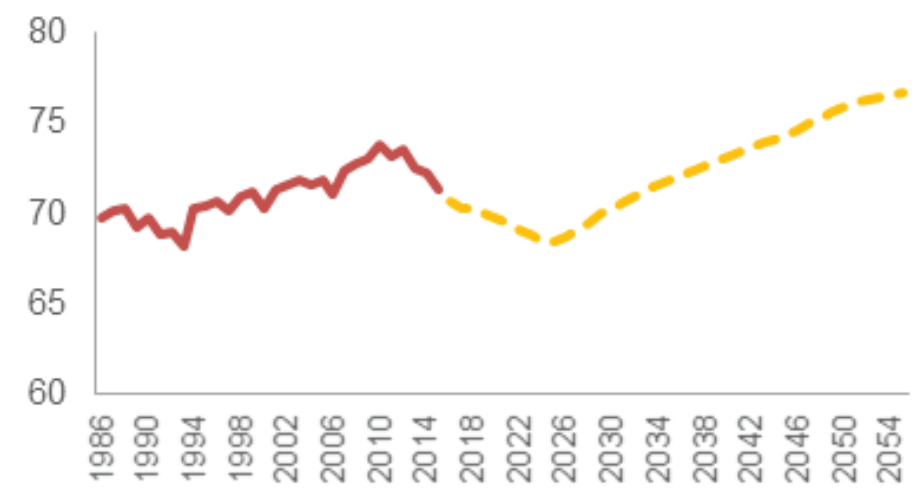

Figure 3 Projected Participation Rate for Indonesia 1986 - 2054 Source: Authors' calculation

\footnotetext{
7 While our observation data is ranging from 1984 to 2015, we limit the productivity growth rate data only from 2000 to 2015 in order to localize the potential effect of Asian Financial Crisis occurred in 1997-1998. We believe that putting those period's data into the calculation would cause underestimate the result. In addition, even though the crisis occurred in 1997, it took times for Indonesia to recover from the crisis. Based on several macroeconomic indicators, we argue that Indonesia has started to recover-although
} 
general. Secondly, this study categorized the populations based on age and projected the participation rate for each age group in order to bring the detailed trend of the rate by age group. The result of this projection is shown in Figure 3 and 4.

Figure 3 illustrates historical participation rate and its prediction. The figure shows that, overall, there will be a decreasing trend of participation rate from 2016 to 2024, followed by a rebound. Since then, the participation rate continues to increase throughout the years up to approximately $75 \%$ in 2050.

While Figure 3 shows the trend of participation rate and the projection in general, Figure 4 depicts the same rate at a more detailed using several age groups. Figure 4 reveals that except for one group, all other age groups show either an increasing trend or stable level. The age group of 15-19 years old shows an extreme decline and reach the horizontal axis. When this paper calculates the year of schooling in a simple method, this study finds that year of schooling for Junior High School (JHS) graduate is 9 years added to the normal age of elementary school enrollment -6 to 7 years old-then this study finds that age 15-19 is a JHS graduate who quit the next formal education and enters labor market. Therefore, it is argued that the declining trend is caused by the improvement in educational level, to the extents that year of schooling increases and encourages person at age 15-19 years old to stay in the school.

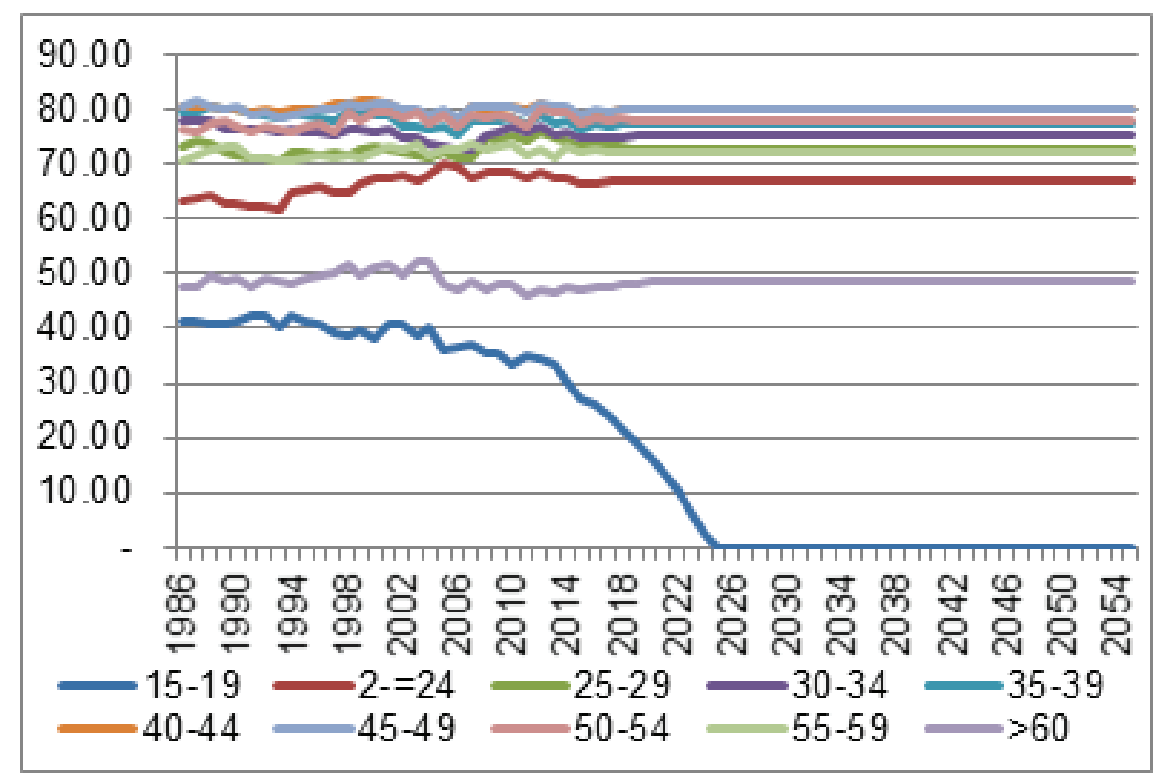

Figure 4 Participation Rate for Each Age Group (in percent, 1986-2054) Source: Authors' calculation 


\subsection{GDP Projection}

After three components of income per capita are constructed, this study will be able to estimate GDP per capita and then GDP projection. In general, the GDP per capita growth rate is predicted to be relatively constant around 4 percent each year as presented in Figure 5. Moreover, if the productivity is assumed to constantly grow at 3.6\% annually, then the roles of participation and proportion of the working age are significantly different.
For example, before 2025, the growth is supported by the proportion of the working age, while the participation of working age in the labor force will drag down the growth. Conversely, after 2025, the participation will replace the role of proportion to support growth, since the dependency ratio will increase at around 2025.

The increasing role of participation component implies that the rise of the labor force will relatively higher than the working age. On the other hand, the declining on the working age proportion implies that the number of the ageing populations does have a significant effect on the proportion of the populations.

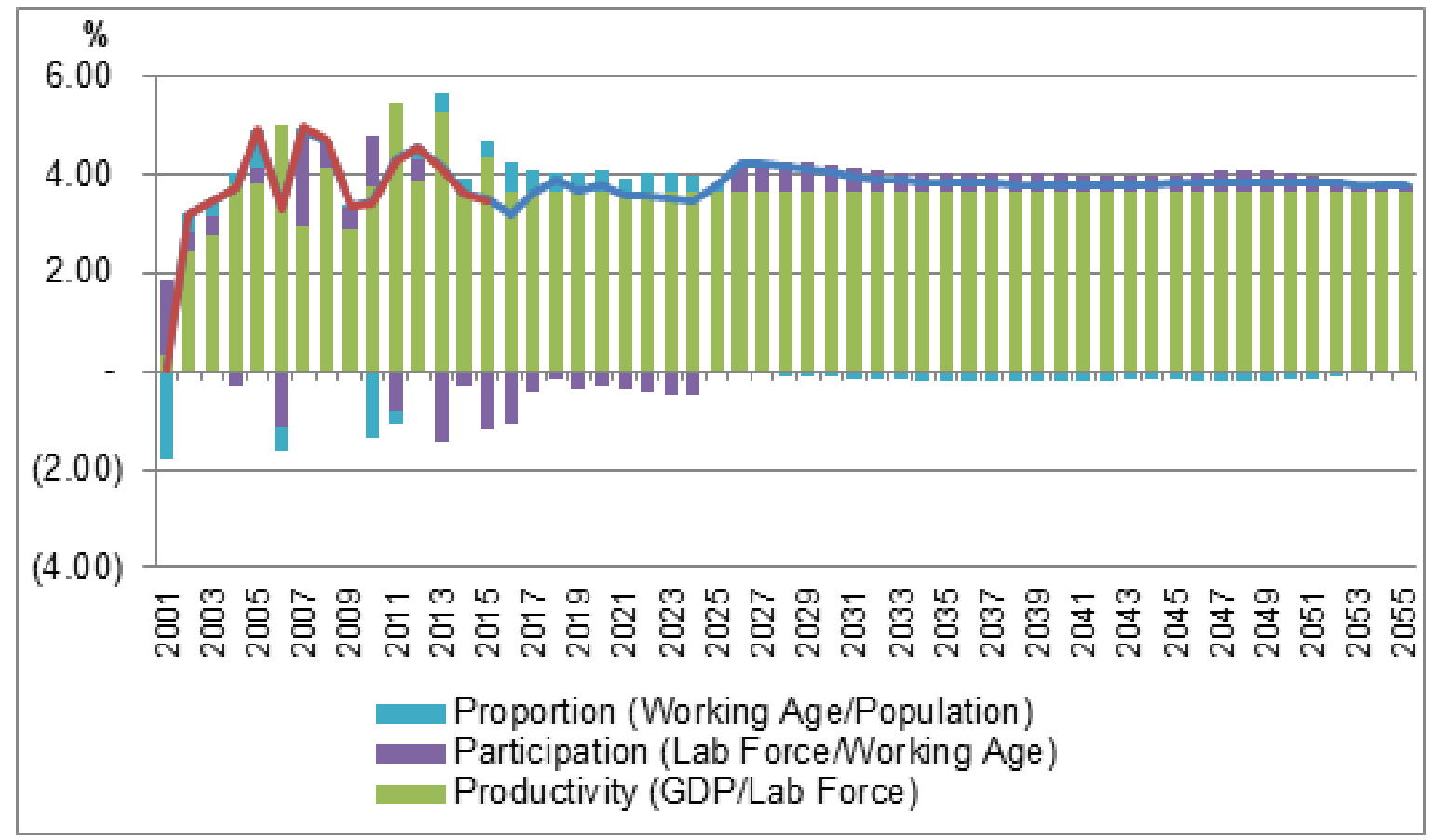

Figure 5 Projection of GDP per Capita Growth Decomposition (in percent, 2001-2055) Source: Authors' calculation 


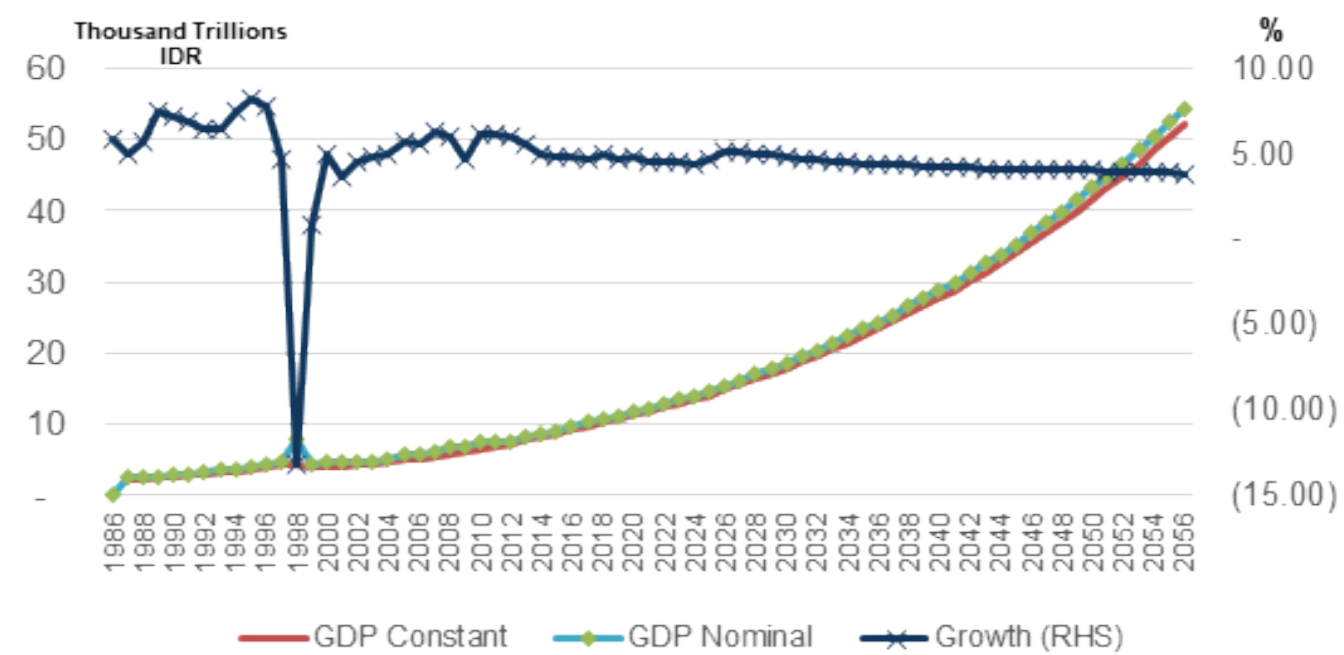

Figure 6 GDP \& GDP Growth Projection (Period 1986-2055) Source: Authors' calculation

In short, this study argues that both in the short and long run, productivity is a dominant factor in the GDP per capita growth. Nevertheless, two other components, such as participation rate and working age proportion have different roles which seem relatively in an opposite trend.

After GDP per capita growth is established, the next step is to calculate GDP both in nominal and real value. The multiplication of GDP per capita growth with the actual value of GDP per capita in 2015 constructs the GDP per capita for the period of 2016-2055. After the GDP per capita is obtained, GDP in constant value is simply a multiplication of GDP per capita to total populations, while GDP in nominal value is defined by multiplying the GDP constant value with estimated inflation rate.

Figure 6 reveals that despite gradual declining in GDP growth projection, GDP still increases significantly. It is projected that by 2020 and 2055, the value of GDP at constant and nominal value will reach at approximately 11,456 trillion IDR and 48,807 trillion IDR respectively. In other words, in 2055 the GDP will be quintuple compared to 2015 GDP at around 8,566 trillion IDR.

\subsection{State Budget Projection}

This paper only estimates revenue and expenditure sides, while financing is defined as merely residual of those two accounts. This study estimates the revenue side first, then continues to the expenditure side.

In terms of revenue side, this study differentiates between demographic and non-demographic revenues. In particular, this study utilises a simple regression of revenue for each article and the number of the labor force in natural logarithm value. This transformation implies that for every $1 \%$ growth of labor force should increase the particular article by particular percentage. For example, for Article 21, which is an income tax for the employee, for each $1 \%$ increase of labor force, should 
increase the revenue by $8.1 \%$. Similarly, for each increase in the growth rate of the labor force will increase the revenue from Article 25/29 of personal tax by $8.4 \%$. The last article is a tax which is calculated at each end of the month and year by the taxpayers which is essential in trying to capture the entrepreneurship of non-employee.
For another component of revenue account, the estimate is based on fix percentage to GDP as presented in Table 1 (Appendix). The percentage value to GDP nominal is the value of 5 years average of ratios for each component of nominal GDP. Another components which are minor still included in the calculation, for instance, Foreign Fiscal Revenue and government payment for income tax.

Table 2 Elasticity Estimation for Article 21 and Article 25/29 Personal Taxpayers Source: Authors' calculation

\begin{tabular}{|c|c|c|}
\hline Dependent & $\begin{array}{c}\text { Article } 21 \\
\text { Income Tax }\end{array}$ & $\begin{array}{l}\text { Article } 25 / 29 \\
\text { Income Tax }\end{array}$ \\
\hline 1 & 2 & 3 \\
\hline Intercept & $\begin{array}{c}-139.982^{* \star *} \\
(4.879)\end{array}$ & $\begin{array}{c}-134.165^{\star \star *} \\
(26.935)\end{array}$ \\
\hline Labor Force & $\begin{array}{c}8.134^{\star * *} \\
(0.264)\end{array}$ & $\begin{array}{c}8.408^{\star * \star} \\
(1.451)\end{array}$ \\
\hline
\end{tabular}

Note: 1 Estimation period: 1997-2015; 2 Estimation period: 2005-2015; *** Significancy level at 1\%; Standard errors are in parentheses.

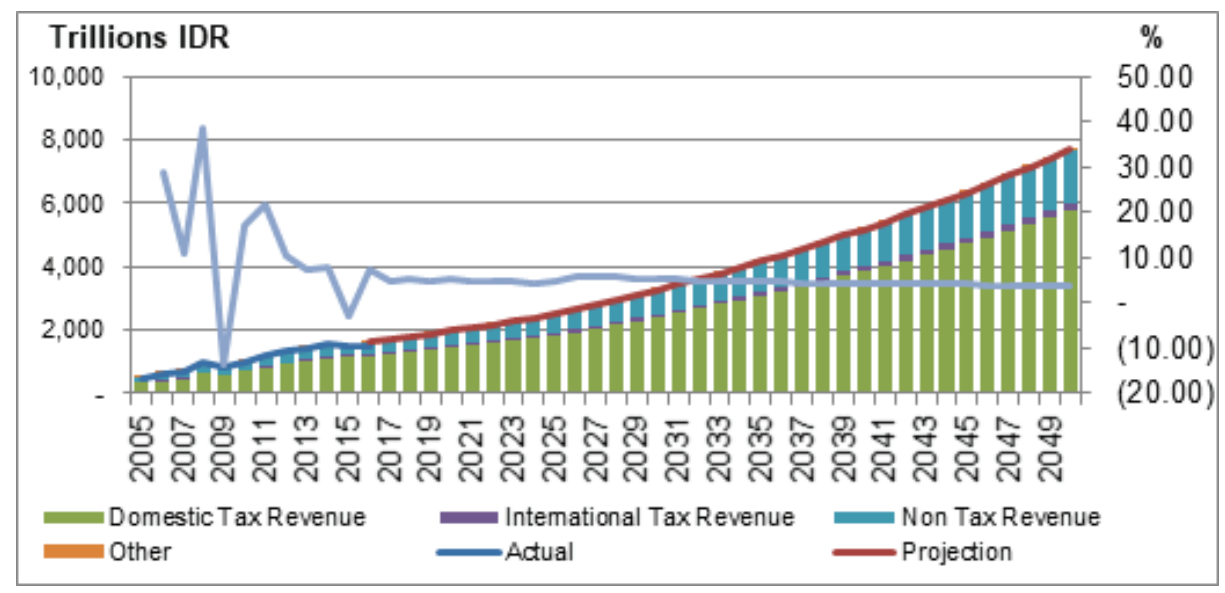

Figure 7 Revenue Actual, Projection (in Trillion IDR) and Growth Rate (in percent) Source: Authors' calculation

\footnotetext{
${ }^{8}$ Other way to project demographic transition is to calculate economic growth based on demographic changes, then calculates tax revenue growth based on economic growth. This concept is known as tax buoyancy, which measures responsiveness of tax revenue to economy. However, this method cannot differentiate between demographic factor and non-demographic factor. Thus, this study utilises linear estimation to obtain elasticity of tax revenue per article.
} 
After the ratio and elasticity for each component of revenue can be estimated, the total revenue with the major components is presented in Figure 7. Figure 7 reveals that in terms of revenue composition, domestic tax revenue dominate over time, which is followed by the non-tax revenue. However, the grants are the smallest contributor on the revenue side. Regarding the growth rate, it is projected that the rates are around $4-5 \%$ with a tendency to decline gradually.

Consequently, the expenditure projection which is assumed to grow similarly to GDP is presented in Figure 8. In this figure, it is assumed that education and health appropriations are around $20 \%$ and $5 \%$, to fulfil the mandatory spending. In addition, it is assumed that $50 \%$ of the expenditure is allocated to the local governments through transfers. These percentages are kept constant for all projected years.

Since revenue and expenditure sides already projected in the previous section, now the state budget can be projected. In general, as presented in Figure 9 , the state budget will under deficit up to 2050. The ratio of deficit to GDP will reach its peak in 2016 with around 3.3\% of GDP. Since then, the deficit tends to decrease gradually up to 2043 at around 2\% before slowly increasing up to 2050.

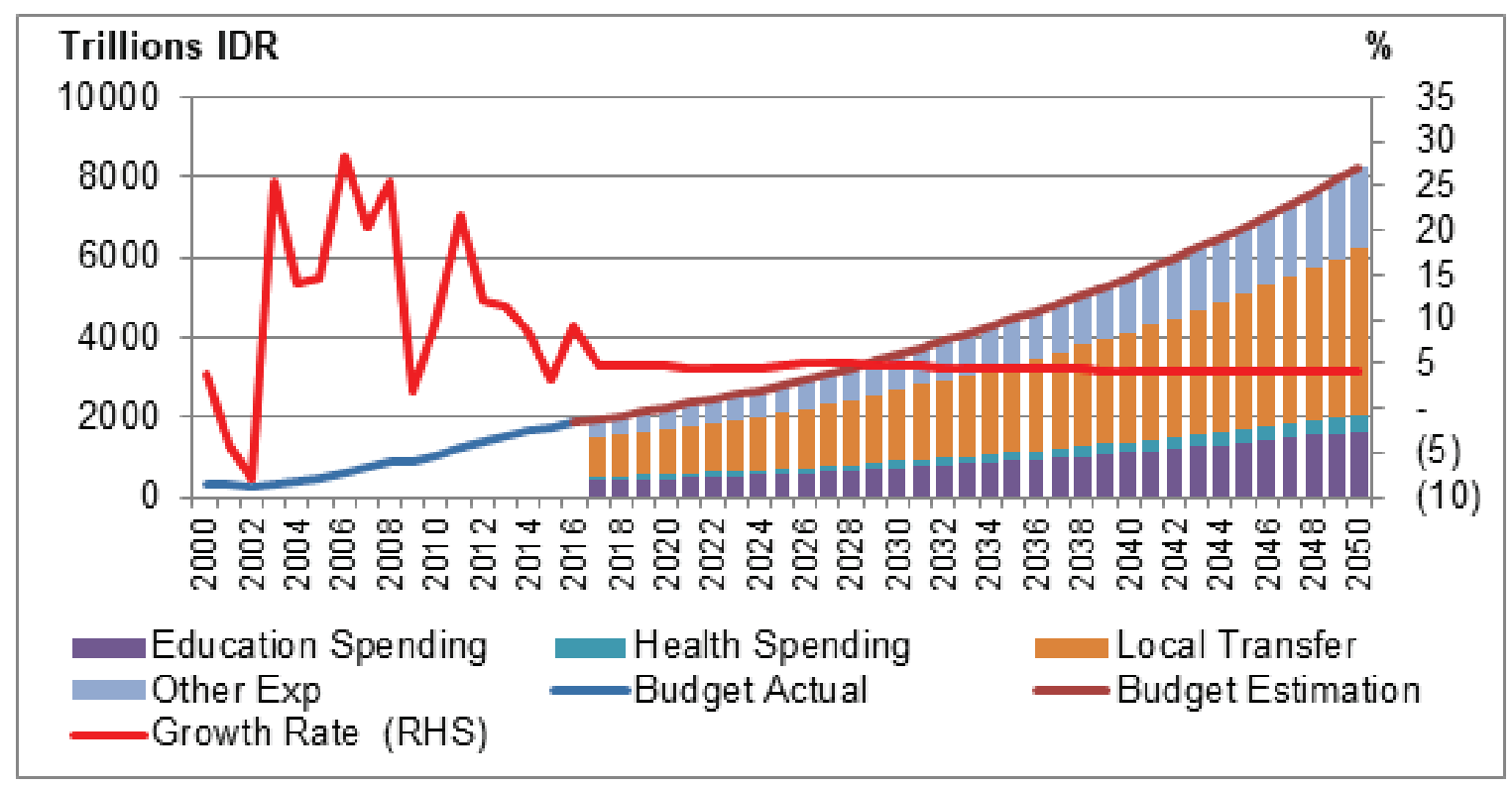

Figure 8 Expenditure Actual and Projection (in Trillion IDR) Source: Authors' calculation 


\section{Trillions IDR}

12,000

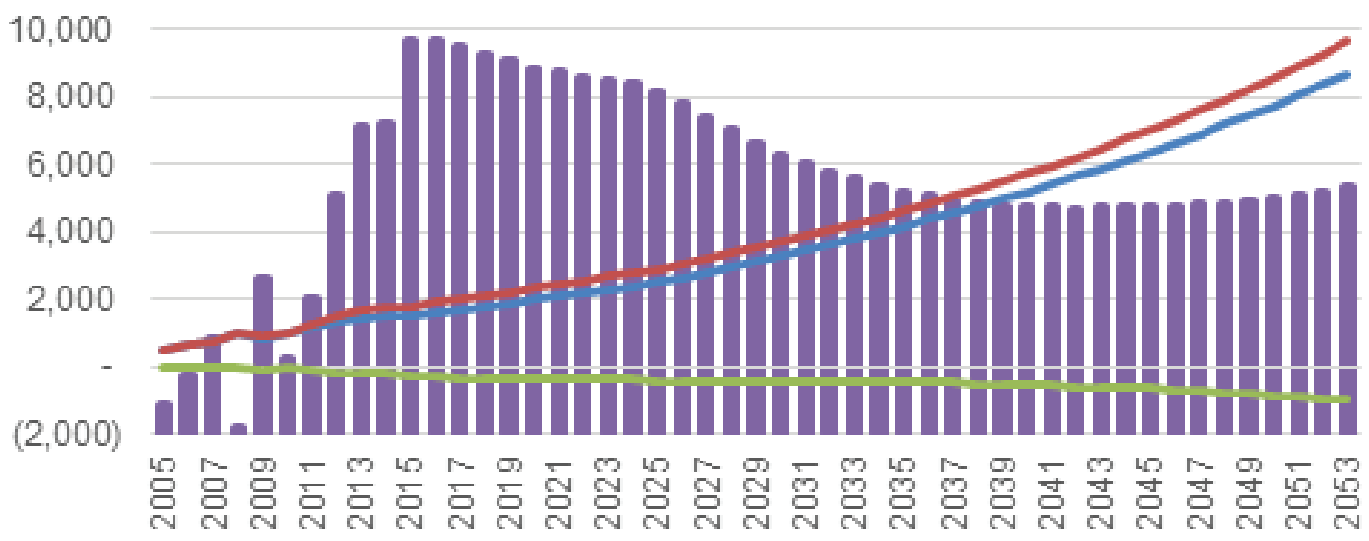

\% to GDP (RHS) - Revenue Expenditure - Deficit

Figure 9 Budget Decomposition and Deficit

Source: Authors' calculation

\subsection{The Importance of Extending and Maintaining Tax Base}

Hitherto, this study presents the dynamic of state budget due to demographic transition by utilizing the 3P model in Equation 1. Hence, this section explores in more details, the estimation of tax revenue by Income Tax Law's Article based on demographic and non-demographic factors.

The effects of demographic changes to tax revenue is clearly presented in Figure 10. The figure reveals that initially, tax revenue proportion from Article 25/29 Personal Taxpayers were relatively low compared to other Articles. The top contributors were Article 25/29 Firm and Article 21. However, in the long run, Article 21 will take over the first position in contribution which is due to demographic transition. This change could be due to increasing number of the working forces, in particular formal labor force in the market as productive age cohort increase.

Thus, the main argument of this section is that tax base extension should be a priority in the current policy for several reasons. Firstly, one way to increase tax revenue growth rate is by extending the tax base. Most of the developed countries have dominant role of Personal Taxpayers by around $80 \%$. Indonesia, on the other hand, has relatively lower percentage tax contribution from employee or entrepreneur. Secondly, the proportion rate due to demographic transition indicates that tax revenues from this component should be optimised before 2025, since after 2025 the number of working age populations will be slowing down while the number of non-productive cohort will start to increase gradually. In other words, policy to extend the number of taxpayers (from non-registered to registered) should be 
implemented earlier rather than later. Similarly, starting from 2025, the participation rate will be more dominant, thus, policy to maintain the expectation of the taxpayers should be prioritised. To overcome this issue, there are several strategies. Firstly, implementation of early tax education in the formal education. This strategy focus on sharing sufficient knowledge and awareness to each labor force on the importance of tax revenue and contribution of each employee or entrepreneur. Secondly, increasing tax transparency through tax expenditure report ${ }^{9}$. By providing more data or report for public, taxpayers will be able to monitor and evaluate current state of tax revenue as well as state budget.

\section{CONCLUSIONS AND POLICY RECOMMENDATIONS}

Based on current and future transition on Indonesian demographic, this paper's main objective is to construct a correlation between demographic and the state budget, in particular tax revenue. In general, this study finds that demographic bonus will be beneficial for Indonesia for several reasons. Firstly, the proportion of working age supports Indonesian GDP per capita growth up to 2025. As a result, the state budget's deficit will tend to decrease up to 2043. Nevertheless, after the bonus era is over, the demographic issue will drag down the economic growth due to ageing populations which is indicated by increasing dependency ratio.

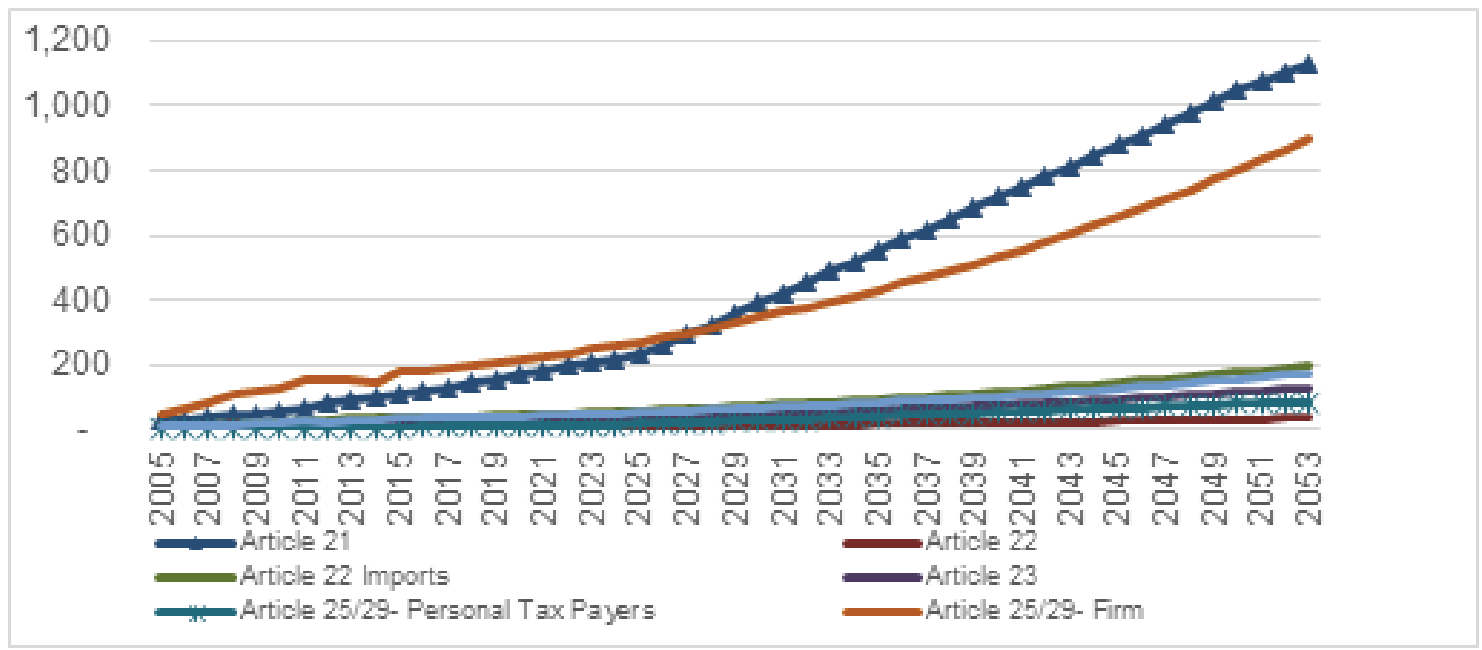

Figure 10 Tax Revenue Projection by Article Source: Authors' calculation 
Thus, this study argues that extending tax base should be an initial strategy to cope with this demographic issue. After the slow-down of productive labor force in 2025, the main strategy is to maintain the taxpayers' expectation by improving state budget transparency. There are several ways to exercise both strategies, such as early formal tax education while providing clear report on tax revenue through tax expenditure report.

\section{REFERENCES}

[1] Araki, S. \& Claus, I. (2014). A Comparative Analysis of Tax Administration in Asia and The Pacific. Mandaluyong City, Philippines: Asian Development Bank.

[2] Australian Treasury. (2015). 2015 Intergenerational Report: Australia in 2055. Canberra, ACT: Author. Retrieved from https://treasury.gov.au/sites/default/files/2019-03/2015_IGR.pdf

[3] Chong-Bum, A. \& Seung-Hoon, J. (2006). Demographic change and economic growth. An inverted-U shape relationship. Economics Letters, 92, 447-454. doi: 10.1016/j.econlet.2006.03.030.

[4] Choudhry, M.T. \& Elhorst, J.P. (2010). Demographic transition and economic growth in China, India and Pakistan. Economic Systems, 34(3), 218-236. doi: 10.1016/j.ecosys.2010.02.001.

[5] Golley, J. \& Wei, Z. (2015). Populations dynamics and economic growth in China. China Economic Review, 35, 15-32. doi: 10.1016/j.chieco.2015.05.005.

[6] de la Croix, D., Lindh, T. \& Malmberg, B. (2009). Demographic change and economic growth in Sweden: 1750-2050. Journal of Macroeconomics, 31(1), 132-148. doi: 10.1016/j.jmacro.2007.08.014.

[7] Lee, S.H. \& Mason, A. (2007). Who gains from the demographic dividend? Forecasting income by age. International Journal of Forecasting, 23(4), 603-619. doi: 10.1016/j.ijforecast.2007.07.004.
[8] Lindauer, D.L. \& Velenchik, A.D. (1992). Government Spending in Developing Countries: Trends, Causes, and Consequences. The World Bank Research Observer, 7(1), 59.78.

[9] Mao, R., \& Xu, J. (2014). Populations Aging, Consumption Budget Allocation and Sectoral Growth. China Economic Review, 30, 44-65. doi: 10.1016/j.chieco.2014.05.004.

[10] Oosthuizen, M.J. (2014). Bonus or mirage? South Africa's demographic dividend. The Journal of the Economics of Ageing, 5, 14-22. doi: 0.1016/j.jeoa.2014.08.007.

[11] Prskawetz, A., Fent, T., Barthel, W., Crespo-Cuaresma, J., Lindh, T., Malmberg, B., \& Halvarsson, M. (2007). The Relationship Between Demographic Change and Economic Growth in the EU. Vienna: Institut für demographie österreichische akademie der wissenschaften. Retrieved from https://www. oeaw.ac.at/fileadmin/subsites/Instit u t e / V I D / P D F / Publications/Forschungsberichte/FB32.pdf.

[12] Shoven, J.B., Topper, M., \& Wise, D.A. (1994). The Impact of the Demographic Transition on Government Spending. In D.A. Wise (Ed.), Studies in the Economics of Aging (pp. 13-38). Chicago: University of Chicago Press.

[13] Stewart, J.S., Oliver, E.G., Cravens, K.S., \& Oishi, S. (2017). Managing Millennials: Embracing Generational Differences. Business Horizons, 60(1) , 45-54. doi: 10.1016/j.bushor.2016.08.011.

[14] United Nation. (2013). National Transfer Account Manual: Measuring and Analysing the Generational Economy. New York: United Nation.

[15] Wolf, D.A. \& Amirkhayan, A.A. (2010). Demographic Change and Its Public Sector Consequences. Public Administration Review Special Issue, S12-S23. 


\section{Appendices}

\begin{tabular}{|c|c|}
\hline Description & \% To GDP Nominal \\
\hline A. Tax Revenue & 12.39 \\
\hline I. Domestic Tax Revenue & 11.84 \\
\hline 1. Income Tax & 5.94 \\
\hline a. Oil \& Gas Income Tax & 0.90 \\
\hline b. Non-Oil \& Gas Income Tax & 4.98 \\
\hline - Article 22 & 0.08 \\
\hline - Article 22 Imports & 0.41 \\
\hline - Article 23 & 0.27 \\
\hline - Article 25/29 Corporate & 1.85 \\
\hline - Article 26 & 0.36 \\
\hline - Final Tax & 0.90 \\
\hline - Others & 0.00 \\
\hline c. Fiscal Revenue & 0.00 \\
\hline - Foreign Fiscal Revenue & 0.00 \\
\hline d. Government paid income tax & 0.06 \\
\hline 2. Value Added Tax & 4.26 \\
\hline a. VAT Revenue & 4.07 \\
\hline - Domestic VAT & 2.54 \\
\hline - Imports VAT & 1.53 \\
\hline - Others VAT & 0.00 \\
\hline b. Luxury Goods Tax & 0.19 \\
\hline c. Government paid VAT & - \\
\hline 3. Property Tax & 0.32 \\
\hline 4. Property Ownerships Tax & $(0.00)$ \\
\hline 5. Excise Revenue & 1.26 \\
\hline 6. Other Tax Revenue & 0.06 \\
\hline II. International Tax Revenue & 0.54 \\
\hline 1. Customs & 0.35 \\
\hline 2. Exports Tax & 0.20 \\
\hline C. Non-tax revenue & 3.98 \\
\hline D. Grants & 0.08 \\
\hline
\end{tabular}

Table 1 Percentage of Revenue Components to Nominal GDP 


\section{Appendices}

\begin{tabular}{|c|c|c|}
\hline No & $\begin{array}{l}\text { Description } \\
\text { (Source) }\end{array}$ & Definition \\
\hline 1 & $\begin{array}{l}\text { GDP at constant } \\
\text { price } \\
\text { (CEIC) }\end{array}$ & $\begin{array}{l}\text { Based on SNA } 2008 \text { with the base year 2010. The data } \\
\text { frequency is annual and in billion IDR. The data is available } \\
\text { in period of } 2010 \text { to } 2015 \text {. Therefore to calculate the } \\
\text { previous period of GDP this study calculate the growth } \\
\text { rate for each different base year of GDP. After that this } \\
\text { study utilises the growth rate to construct the new } \\
\text { constant GDP at the similar base year } 2010 \text {. }\end{array}$ \\
\hline 2 & $\begin{array}{l}\text { GDP at nominal } \\
\text { price }\end{array}$ & $\begin{array}{l}\text { Generated based on GDP at the constant price by utilising } \\
\text { GDP deflator. }\end{array}$ \\
\hline 3 & $\begin{array}{l}\text { GDP Deflator } \\
\text { (World Bank) }\end{array}$ & Extracted from World Bank Economic Indicators. \\
\hline 4 & $\begin{array}{l}\text { Labor Force } \\
\text { (BPS) }\end{array}$ & $\begin{array}{l}\text { Labor force consists of working and non-working people } \\
\text { in working age. }\end{array}$ \\
\hline 5 & $\begin{array}{l}\text { Working age } \\
\text { (BPS) }\end{array}$ & $\begin{array}{l}\text { In this study working age group is defined as a group of } \\
\text { people who age is between } 15 \text { to } 65 \text { years old. The upper } \\
\text { limit is important to calculate dependency ratio in which } \\
\text { measures the ratio of dependent groups (below } 15 \text { years } \\
\text { old and over } 65 \text { years old). }\end{array}$ \\
\hline 6 & $\begin{array}{l}\text { Populations } \\
\text { (BPS) }\end{array}$ & $\begin{array}{l}\text { The total populations which is can be decomposed based } \\
\text { on different age cohorts. }\end{array}$ \\
\hline 7 & GDP per Capita & $\begin{array}{l}\text { Calculated simply by dividing the GDP by constant price to } \\
\text { total populations }\end{array}$ \\
\hline 8 & Productivity & $\begin{array}{l}\text { Calculated as a ratio of GDP at constant price and labor } \\
\text { force }\end{array}$ \\
\hline 9 & Participation & Calculated as a ratio of labor force to total working age \\
\hline 10 & $\begin{array}{l}\text { Proportion of } \\
\text { working age }\end{array}$ & A ratio of working age to total populations \\
\hline 11 & Growth rate & $\begin{array}{l}\text { Calculated based on year on year growth. This study } \\
\text { computes growth rate for GDP at the constant price as well } \\
\text { as budget growth rate, in particular revenue and } \\
\text { expenditure growth rates. }\end{array}$ \\
\hline 12 & $\begin{array}{l}\text { Revenue } \\
\text { (LKPP- Audited } \\
\text { Government } \\
\text { Financial Report) }\end{array}$ & $\begin{array}{l}\text { Revenue can be decomposed into tax revenue, non-tax } \\
\text { revenue, and grants. The tax revenue consists of domestic } \\
\text { and international tax revenues. }\end{array}$ \\
\hline 13 & Expenditure & $\begin{array}{l}\text { Total expenditure both for as planned in the state budget } \\
\text { and realisation. }\end{array}$ \\
\hline 14 & Financing & $\begin{array}{l}\text { Basically, this component is the gap between revenue and } \\
\text { expenditure. If expenditure > revenue, the financing is } \\
\text { needed. }\end{array}$ \\
\hline
\end{tabular}

